\title{
Proteome analysis of nuclear matrix proteins during apoptotic chromatin condensation
}

\author{
C Gerner, ${ }^{\star,}$, J Gotzmann ${ }^{1}$, U Fröhwein ${ }^{1}$, C Schamberger ${ }^{1}$, \\ A Ellinger ${ }^{2}$ and $G$ Sauermann ${ }^{1}$ \\ 1 Institute of Cancer Research, University of Vienna, A-1090 Vienna, Austria \\ 2 Institute of Histology and Embryology, University of Vienna, A-1090 Vienna, \\ Austria \\ * Corresponding author: C Gerner, Institute of Cancer Research, University of \\ Vienna, Borschkegasse 8a, 1090 Vienna, Austria. Tel: (43) 14277 65230; \\ Fax: (43) 14277 9651; E-mail: Christopher.Gerner@univie.ac.at
}

Received 26.6.01; revised 20.12.01; accepted 8.1.02

Edited by $S$ Martin

\begin{abstract}
The nuclear matrix (NM) is considered a proteinaceous scaffold spatially organizing the interphase nucleus, the integrity of which is affected during apoptosis. Caspasemediated degradation of NM proteins, such as nuclear lamins, precedes apoptotic chromatin condensation (ACC). Nevertheless, other NM proteins remain unaffected, which most likely maintain a remaining nuclear structure devoid of chromatin. We, therefore, screened various types of apoptotic cells for changes of the nuclear matrix proteome during the process of apoptotic ACC. Expectedly, we observed fundamental alterations of known chromatin-associated proteins, comprising both degradation and translocation to the cytosol. Importantly, a consistent set of abundant NM proteins, some (e.g. hNMP 200) of which displaying structural features, remained unaffected during apoptosis and might therefore represent constituents of an elementary scaffold. In addition, proteins involved in DNA replication and DNA repair were found accumulated in the NM fraction before cells became irreversibly committed to ACC, a time point characterized in detail by inhibitor studies with orthovanadate. In general, protein alterations of a consistent set of NM proteins (67 of which were identified), were reproducibly detectable in Fasinduced Jurkat cells, in UV-light treated U937 cells and also in staurosporine-treated HeLa cells. Our data indicate that substantial alterations of proteins linking chromatin to an elementary nuclear protein scaffold might play an intriguing role for the process of ACC.

Cell Death and Differentiation (2002) 9, 671-681. DOI: 10.1038/ sj/cdd/4401010
\end{abstract}

Keywords: apoptosis; 2D electrophoresis; chromatin condensation; nuclear scaffold

Abbreviations: 2D, two-dimensional; ACC, apoptotic chromatin condensation; aa, amino acid; DFF-45, DNA fragmentation factor 45 kDa subunit; $h n R N P$, heterogeneous nuclear ribonucloprotein; hsp, heat shock protein; Mw, molecular weight; NM, nuclear matrix; NMP, nuclear matrix protein; PARP, Poly [ADP-ribose] polymerase; pl, isoelectric point

\section{Introduction}

The highly insoluble non-chromatin proteins of the nucleus, termed nuclear matrix proteins (NMPs), have been implicated in vital processes, such as DNA replication and transcription, RNA processing and transport as well as ribosomal biogenesis. ${ }^{1,2}$ In our systematic proteome studies on human NMPs from various cellular sources cell type-specific, cell state-specific and common NMPs ubiquitously occurring in various cell types, have been differentiated and some identified. ${ }^{3-6}$ A subgroup of common NMPs was described that exerted an enhanced capability of reassembling, thus representing a source for potential structural nuclear proteins. ${ }^{7-9}$ Investigation of proteome alterations accompanying well-defined physiologic processes may help to further characterize and understand functional implications of affected proteins. We, therefore, focused this study on the fate of NMPs during apoptotic chromatin condensation (ACC).

Apoptosis is a genetically determined program for cell death. Highly conserved throughout evolution, it plays a role in various normal and pathological biological processes. ${ }^{10,11}$ Apoptosis is morphologically signified by cytoplasmic shrinkage, active membrane blebbing and condensation of chromatin close to the inner linings of the nuclear envelope. In the course of these processes certain proteins are cleaved by a set of activated, extraordinarly selective proteases, designated as caspases. ${ }^{12-14}$ Of the NMPs the lamins $A / C$ and $B$, NuMA, hnRNP proteins $C 1$ and $\mathrm{C} 2$, the $70 \mathrm{kD}$ component of $\mathrm{U} 1$ small ribonucleoprotein (snRNP), the scaffold-attachment factor A (SAF-A or $\mathrm{hn}$ RNP $U$ ) and the special AT-rich sequence-binding protein 1 (SATB1) have been identified as caspase targets, while other NMPs have been found unaffected. ${ }^{15-23} \mathrm{~A}$ general mechanism underlying chromatin condensation has not yet been established. Endonuclease-induced chromatin cleavage at internucleosomal sites, ${ }^{24,25}$ histone deacetylation modifying protein-DNA interactions ${ }^{26}$ and the action of the caspase-3-activated protein acinus ${ }^{27}$ have been implicated.

In the present study, proteome alterations during ACC evidenced by comparative 2D-gel analysis were investigated in detail. It was expected that these proteome data might shed light on the presumed contribution of nuclear proteins to the structural re-organization of the nucleus during ACC. The data show that similar protein alterations occur largely independent of the cell system and of the apoptosis-induction mechanism. Several abundant nuclear matrix proteins capable of binding chromatin were found depleted during ACC. Following disruption of chromatinnuclear matrix interactions and condensation of chromatin, 
a non-chromatin nuclear structure apparently remains. Another subset of abundant common nuclear matrix proteins was found to remain, putatively including core proteins necessitated for maintenance of an elementary nuclear scaffold.

\section{Results}

\section{Evidence for a residual nuclear scaffold uncovered during ACC}

Apoptosis was induced in Jurkat cells by treatment with $50 \mathrm{ng} /$ $\mathrm{ml}$ anti-CD95 (anti-Fas) antibody, as detailed recently. ${ }^{22,28}$ Electron microscopy and DNA staining of apoptotic cells displayed condensed chromatin along the nuclear periphery (Figure 1B,D), leaving the nuclear membrane still discernible (Figure 1B,C). Apparently, structured nuclear areas disclosed by condensed chromatin remained, indicating the existence of a residual core nuclear scaffold (Figure 1B,E).

To investigate, whether specific proteins would contribute to this potential scaffold, we analyzed the subcellular localization of one prominent nuclear matrix protein member with structural functions, hNMP $200 .^{9}$ HeLa cells expressing a hNMP 200-GFP fusion protein were induced to undergo apoptosis by treatment with $2.5 \mu \mathrm{M}$ staurosporine. In untreated cells colocalization of hNMP 200 and chromatin, except in nucleolar regions, was evident (Figure $1 \mathrm{E}, \mathrm{F})$. However, within nuclei displaying condensed chromatin, hNMP 200 was found relocalized to nuclear areas devoid of chromatin, and was undetectable within areas of condensed chromatin (Figure $1 \mathrm{G}, \mathrm{H}$ ). Thus, hNMP 200 might structurally contribute to a residual core nuclear scaffold, visualized under the electron microscope (Figure 1B). By proteome analysis we further investigated the fate of many other nuclear matrix proteins during ACC.

\section{Orthovanadate treatment determines the point of no return for apoptotic chromatin condensation}

We observed that the chromatin condensation process was efficiently inhibited when treating Fas-induced Jurkat cells with orthovanadate just before onset of $A C C$, i.e. the nuclei remained intact within the following time period. As expected, caspase-3, PARP and DFF-45 were found completely processed $8 \mathrm{~h}$ after Fas-induction, at a time when virtually all nuclei displayed ACC (Figure 2). However, when supplementing the medium with $300 \mu \mathrm{M}$ orthovanadate at $2.5 \mathrm{~h}$ after Fas-induction, and additional incubation of cells for $5.5 \mathrm{~h}, \mathrm{ACC}$ was completely inhibited during this period of time as determined by HOECHST staining (not shown). Under this conditions procaspase- 8 was found already processed, as was a considerable portion of procaspase-3, whereas PARP and DFF-45 remained largely unaffected by caspases (Figure 2). When supplementing the medium with $300 \mu \mathrm{M}$ orthovanadate at $3.5 \mathrm{~h}$ after Fas-induction, and additional incubation of cells for $4.5 \mathrm{~h}$, all cells displayed ACC. We concluded that by orthovanadate-treatment the processes resulting in ACC were inhibited in a critical manner, allowing to conclude for a
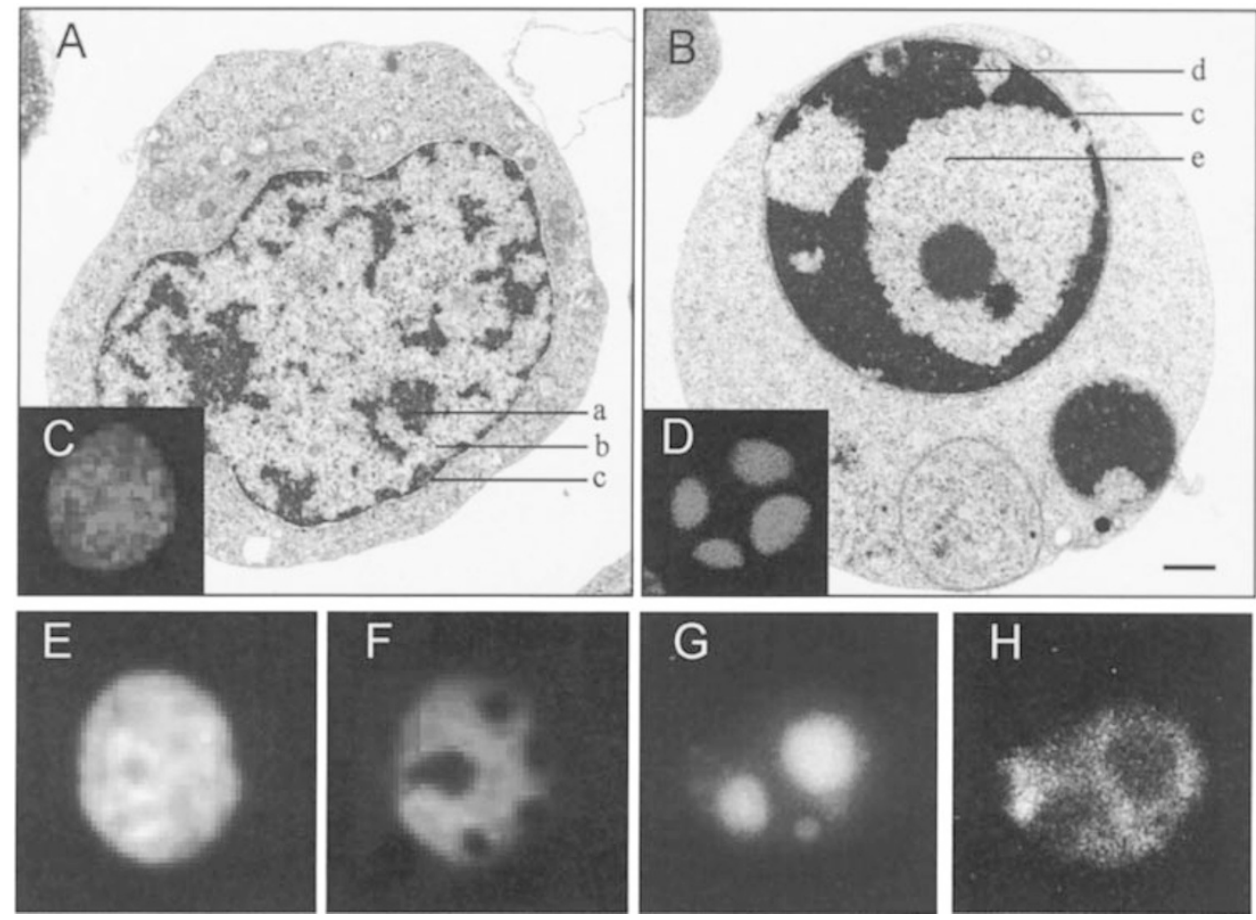

Figure 1 Chromatin condensation discloses nuclear areas largely free of chromatin. Electron microscopy of a control (A) and an apoptotic (B) Jurkat cell displaying condensed chromatin. a, heterochromatin; b, euchromatin; c, nuclear envelope; d, condensed chromatin; e, electron translucent, chromatin-reduced nuclear area; Scale bar: $1 \mu \mathrm{m}$; (C) propidium iodide stain of a control Jurkat cell; (D) propidium iodide stain of an apoptotic Jurkat cell. E-H, GFP-hNMP 200 expressing HeLa cells either untreated (E, F) or staurosporine-treated (G, H). E, G, Hoechst chromatin staining; G, H, GFP-fluorescence. In uncondensed nuclei, hNMP 200 and chromatin colocalize, after condensation of chromatin the localization of hNMP 200 and chromatin becomes mutually exclusive 


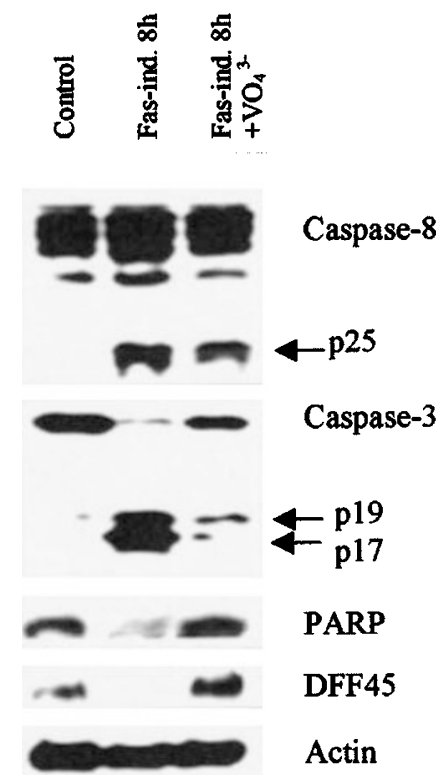

Figure 2 Orthovanadate treatment interferes with caspase activity. Whole cell lysates of untreated Jurkat cells (Control), $8 \mathrm{~h}$ after Fas-induction (Fas-ind. $8 \mathrm{~h}$ ) and $8 \mathrm{~h}$ after Fas-induction, supplementing the medium with $300 \mathrm{nM}$ orthovanadate $2.5 \mathrm{~h}$ after Fas-induction (Fas-ind. $8 \mathrm{~h}+\mathrm{VO}_{4}{ }^{3-}$ ) were immunoblotted with antibodies against the indicated proteins. While active initiator caspase- 8 remained detectable in orthovanadate-treated cells, further processing of caspase- 3 and cleavage of the caspase targets PARP and DFF-45 was apparently inhibited

time point when nuclei were irreversibly committed to ACC by $3 \mathrm{~h}$ after Fas-induction. In order to interpret proteome analysis data accordingly, we decided to compare nuclear matrix preparations isolated from untreated cells (i.e. control) with those three hours after Fas-treatment (i.e. irreversibly committed to ACC) and those $8 \mathrm{~h}$ after Fas-treatment (i.e. essentially after completion of ACC).

\section{Comparative analysis of the nuclear matrix protein composition during Fas-induced apoptosis in Jurkat cells}

By two-dimensional electrophoresis (2-DE) of nuclear matrix preparations of control Jurkat cells, 316 spots were reproducibly resolved within the range of $\mathrm{pl} 3.5-7.5$ and $20-200 \mathrm{kDa}$ (Figure 3). At $3 \mathrm{~h}$ after Fas-induction, 20 of these spots were found significantly decreased (integrated spot intensity $<0.5 \times$ control, see also Table 1 ), as indicated by short arrows in Figure 4 . On the other hand, 11 spots displayed at least twofold increased intensities (Table 2), as designated by large arrows in Figure 4. Furthermore, 14 new nuclear matrix protein spots appeared (rectangles in Figure 4, Table 2). After $8 \mathrm{~h}$ of Fas-induction, 285 spots of the above mentioned 316 spots were still detectable (spots marked in Figures 3, 4 and 5), i.e. 31 spots had completely disappeared (indicated by circles in Figure 3 and open circles in Figure 5). While further 40 spots were decreased (indicated by minus signs in Figures 3, 4 and 5), the staining intensity of 30 spots was significantly increased (indicated by plus signs in Figures 3, 4 and 5, see also Tables 1 and 2).

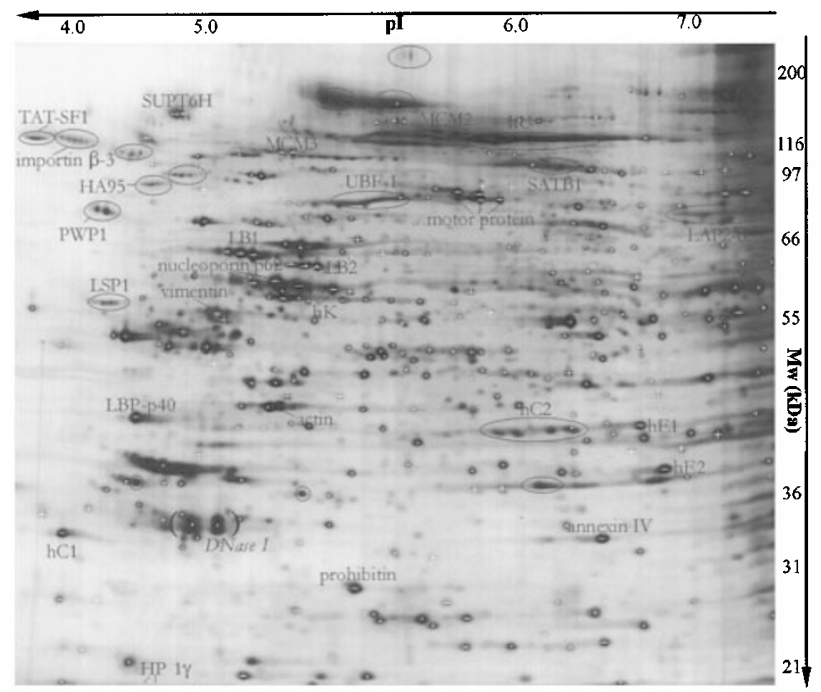

Figure 3 Nuclear matrix proteins decreasing during apoptosis. 2D nuclear matrix protein pattern of control Jurkat cells. Identified proteins decreasing during apoptosis (Table 1) are indicated. Annotations: circles, disappearing spots; minus signs, decreasing spots; plus signs, increasing spots as observed during ACC. All spots detectable throughout ACC are marked to facilitate pattern comparison. Exogenously added DNase I in parentheses

Though only a relatively small number of NMPs was found to disappear, their sum of integrated spot intensities represented approximately one third of the sum of all spot intensities present in control nuclear matrices. Apparently the subgroup of disappearing spots comprised highly abundant nuclear proteins.

\section{Cell-type and stimulus-independent protein alterations during ACC}

We have shown that the majority of NMPs detected by $2-\mathrm{DE}$ are ubiquitously present in different cell and tissue types. ${ }^{3}$ To investigate whether the observed NMP alterations were indeed related to ACC, we analyzed cell models for apoptosis other than Fas-treated Jurkat cells. Varying the apoptosis induction mechanisms, we treated Jurkat cells with UV-light, camptothecin or staurosporine. In addition, apoptosis was induced by exposing human U937 monocytic leukemia cells to anti-Fas antibody, UV-light and staurosporine. Moreover, staurosporine-treated HeLa cells and serum starved rat embryo cells ${ }^{20}$ were investigated. Figure 6 displays the NMP alterations induced by UV-light in U937 cells, most of which were similar to those observed in Fas-induced Jurkat cells (Figures 3, 4 and 5), demonstrating the high similarity of NMP alterations during ACC in various cell types.

Moreover, in each cell system analyzed, type and extent of protein alterations coincided with the progress of chromatin condensation observed by Hoechst staining. Alterations of spot types and spot intensities were essentially the same as observed during Fas-mediated apoptosis in Jurkat cells, including decreasing, unaffected, increasing and new NMP spots. Differences were found mainly due to the slightly different NMP composition of different cell lines. Lamins $A / C$ were found cleaved in U937 
Table 1 Nuclear matrix proteins decreasing during ACC (indicated in Figure 3 and 6). Protein alterations were observed in HeLa (H), Jurkat (J) and/or U937 (U) cells as indicated.

\begin{tabular}{|c|c|c|c|c|c|}
\hline \multirow[b]{2}{*}{ hNMP- No. } & \multirow[b]{2}{*}{ Mw/pl } & \multirow[b]{2}{*}{ protein name/spot designation } & \multicolumn{3}{|l|}{ Swiss-Prot } \\
\hline & & & GenBank Acc. No. & observed in & Identified by \\
\hline 168 & $33 / 6.55$ & annexin IV & P09525 & HJU & $M(11)$ \\
\hline 362,363 & 19/4.7-5.1 & chromobox protein homolog $3(\mathrm{HP} 1 \gamma)$ & Q13185 & HJU & $M(16)$ \\
\hline 227 & $105 / 6.2$ & DNA-binding protein SATB1 & Q01826 & JU & W \\
\hline 356 & $125 / 5.8$ & DNA replication licensing factor $\mathrm{MCM} 2$ & P49736 & HJU & $\mathrm{P}$ (ref. 4) \\
\hline 139,140 & $115 / 5.3$ & DNA replication licensing factor $\mathrm{MCM} 3$ & P25205 & HJU & $M(16)$ \\
\hline 419 & $125 / 3.9$ & $\begin{array}{l}\text { HIV-1 transcriptional elongation factor } \\
\text { TAT cofactor TAT-SF1 }\end{array}$ & $C A B 10730$ & HJU & $\mathrm{M}(14)$ \\
\hline 223 & $34 / 4.4$ & hnRNP C1 (hC1) & P07910 & HJU & $M(8)$ \\
\hline 193 & $39 / 6.4$ & hnRNP C2 (hC2) & P07910 & HJU & $P$ (ref. 3) \\
\hline 301 & $40 / 6.8$ & poly(RC)-binding protein 1 (hnRNP E1) & & HJU & $\mathrm{M}(16)$ \\
\hline 327 & $38 / 6.9$ & poly(RC)-binding protein 2 (hnRNP E2) & Q15366 & HJU & $M(13)$ \\
\hline 135,142 & $60 / 5.3$ & hnRNP K (hK) & Q07244 & HJU & $\mathrm{P}$ (ref. 3) \\
\hline 188 & $120 / 6.35$ & hnRNP U (hU) & Q00839 & HJU & W \\
\hline 353 & $125 / 4.3$ & importin $\beta$-3 & 000410 & HJU & M (14) \\
\hline 262 & 75/7.1/7.9 & $\begin{array}{l}\text { lamina-associated polypeptide } 2 \text { alpha } \\
(\text { LAP } 2-\alpha)\end{array}$ & P42166 & HJU & W (ref. 23) \\
\hline $104-107$ & $66 / 4.9$ & lamin B1 (LB1) & P20700 & HJU & A, W (ref. 3) \\
\hline $148-151$ & $64 / 5.5$ & lamin B2 (LB2) & Q03252 & HJU & A, W (ref. 3) \\
\hline 285 & $55 / 4.4$ & lymphocyte-specific protein LSP1 & P33241 & J & $\mathrm{P}$ (ref. 47) \\
\hline $\begin{array}{l}203,204 \\
214,215\end{array}$ & $\begin{array}{l}90,93 / 5.8-5.9 \\
5.9\end{array}$ & motor protein & $B A A 04656$ & HJU & $\mathrm{M}(29)$ \\
\hline 367 & $95 / 4.6$ & neighbor of A-kinase anchoring protein 95 (HA95) & $N P \_055186$ & HJU & M (29) \\
\hline 217 & $80 / 4.4$ & $\begin{array}{l}\text { nuclear phosphoprotein similar to } \\
\text { S. cerevisiae PWP1 }\end{array}$ & NP_008993 & HJU & $M(11)$ \\
\hline 371 & $90 / 5.3-5.6$ & nucleolar transcription factor 1 (UBF-1) & P17480 & HJU & M (14) \\
\hline 343,344 & $32 / 5.2$ & $\begin{array}{l}\text { nuclear pore glycoprotein P62 } \\
\text { (nucleoporin p62) }\end{array}$ & P37198 & JU & $P$ (ref. 35) \\
\hline 121 & $30 / 5.5$ & prohibitin & P35232 & JU & A, M (16) \\
\hline 576 & $40 / 4.6$ & $40 S$ ribosomal protein SA (LBP-p40) & P08865 & HJU & $A, W, M(11)$ \\
\hline 312 & $150 / 4.9$ & $\begin{array}{l}\text { putative chromatin structure regulator } \\
\text { SUPT6H }\end{array}$ & U46691.1 & HJU & $M(19)$ \\
\hline
\end{tabular}

Protein identification by: $\mathrm{A}$, amino acid sequence; $\mathrm{M}$, mass fingerprinting of tryptic digests with the number of assigned peptides in brackets; $\mathrm{P}$, positions in $2 \mathrm{D}$ gel; $\mathrm{W}$, Western blotting; references are annotated by the prefix ref.

cells and cytokeratin 18 cleaved to a $29 \mathrm{kDa}$ fragment ${ }^{29}$ both in U937 cells and rat embryo cells (spot 13, 14, 15 in ref. ${ }^{20}$ ), but not in Jurkat cells a priori not expressing these proteins (Figure 6A,B versus Figure 3). On the other hand, LSP1, disappearing in Jurkat cells, was not expressed in U937 and other non-lymphoid cells. In the following, protein alterations observed during ACC in Jurkat, U937 and HeLa cells are outlined in detail.

\section{Decrease of nuclear proteins during ACC}

The nuclear matrix of Jurkat cells committed to ACC (3 $\mathrm{h}$ after Fas-induction) displayed only few alterations. In Figure 4 short arrows indicate the spots displaying significantly decreased intensity. Of these, we identified proteins mediating chromosome integrity or described to anchor chromatin to a nuclear protein scaffold, such as SUPT6H, ${ }^{30} \mathrm{HA} 95,{ }^{31}$ nuclear lamins, ${ }^{32}$ LAP $2 \alpha^{23}$ and SATB $1 ; 22$ proteins regulating transcriptional activity such as TAT-SF $1^{33}$ and UBF- $1^{34}$ and nuclear trafficking such as importin $\beta-3,{ }^{35}$ see also Table 1$)$. When almost all nuclei displayed ACC ( $8 \mathrm{~h}$ after Fasinduction), these proteins were essentially undetectable in the NMP fraction (Figure 5, open circles). At that time, a further set of proteins was significantly decreased, including the chromatin-associated proteins LBP-p $40,{ }^{36}$ hnRNP C1, E,
$\mathrm{K}, \mathrm{U},{ }^{37} \mathrm{MCM} 2 / 3,{ }^{38} \mathrm{HP}-1 \gamma,{ }^{39}$ in addition to nucleoporin $\mathrm{p} 62$, annexin IV, prohibitin and an abundant, but yet uncharacterized, motor protein (Figure 5, Table 1).

\section{Proteins accumulating in the NMP fraction during ACC}

Accompanying the decrease of several spots, the intensity of other spots markedly increased (Figures 4, 5, 6B). In addition, appearance of distinct new proteins in the NMP fraction became evident. Only few new and increasing spots were observed at $3 \mathrm{~h}$ after induction of apoptosis. Beside caspasegenerated degradation products of actin, LBP-p40 and lamin $\mathrm{B}$, the intact proteins PCNA, RFC-36 and the ribosomal protein L10E were significantly accumulated (Figure 4, long arrows, Table 2). In addition, cleavage products of myosin and vimentin and derivatives of $\alpha$-actinin and $\alpha$-tubulin were observed, which became detectable as well in the cytosol fraction. $^{28}$

After completed chromatin condensation (8 $\mathrm{h}$ after induction of apoptosis), some proteins originating from the cytoplasm were isolated in the nuclear matrix fraction, as glutathione S-transferase GST- $\pi$, heat shock protein hsp90 and several T-cell complex protein (TCP)-1 isoforms (Figure 4, Table 2). Concomitantly, some of these new 


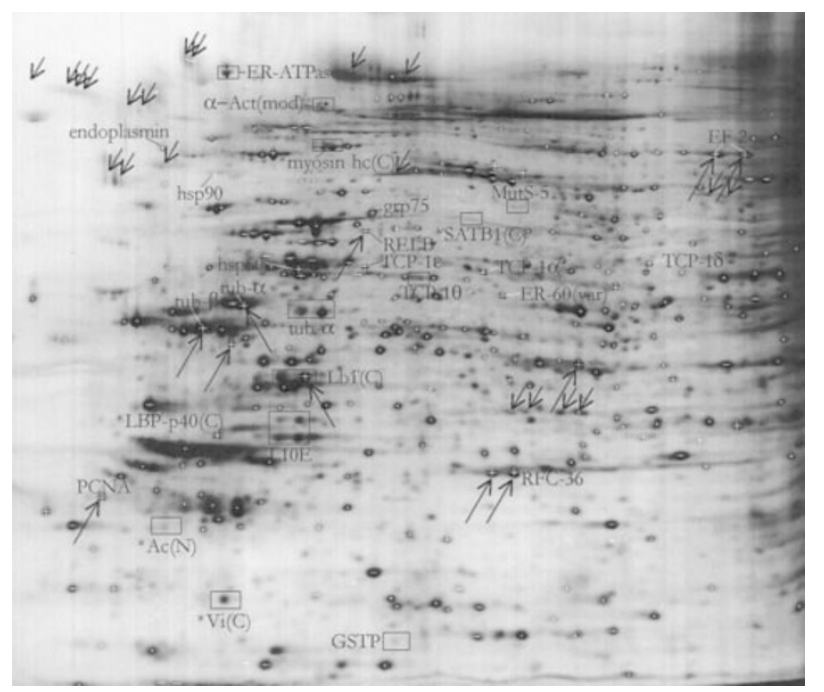

Figure 4 Nuclear matrix proteins increasing or appearing as new spots during apoptosis. 2D nuclear matrix protein pattern of Jurkat cells $3 \mathrm{~h}$ after Fas-induction, thus uniformly committed to ACC. Identified proteins increasing or appearing as a new during apoptosis are indicated (Table 2). Other annotations as in Figure 3; rectangles: newly appearing spots; asterisks: protein cleavage product, $\mathrm{C}$ - or $\mathrm{N}$-terminal part as indicated in parenthesis. To emphasize early alterations, the most rapidly decreasing spots are additionally marked by short arrows, the most rapidly increasing spots by large arrows, respectively



Figure 5 Nuclear matrix proteins maintained during apoptosis. 2D nuclear matrix protein pattern of Jurkat cells $8 \mathrm{~h}$ after Fas-induction, uniformly displaying chromatin condensation. Identified proteins maintained during apoptosis are indicated (Table 3), numbers refer to previously published hNMP-numbers. ${ }^{7}$ Other annotations as in Figure 3 and 4 ; hexagons: abundant proteins maintained during apoptosis; open circles, positions of protein spots that disappeared during apoptosis; rectangles, proteins accumulated during apoptosis as indicated in Figure 4

Table 2 Proteins accumulating in the nuclear matrix fraction during ACC (indicated in Figure 4)

\begin{tabular}{|c|c|c|c|c|}
\hline \multirow[b]{2}{*}{ Mw/pl } & \multirow[b]{2}{*}{ protein name/spot designation } & \multicolumn{3}{|l|}{ Swiss-Prot } \\
\hline & & GenBank Acc. No. & observed in & Identified by \\
\hline $39 / 5.2$ & $60 S$ acidic ribosomal protein P0 (L10E) & P05388 & HJU & M (12) \\
\hline $34 / 4.8$ & actin beta, $\mathrm{N}$-terminal fragment & P02570 & HJU & $\mathrm{M}(9$, aa $20-207)$ \\
\hline $120 / 5.3$ & $\alpha$-actinin 1 , cytoskeletal isoform (modified isoform) & P12814 & HJU & $\mathrm{M}(11)$ \\
\hline $37 / 6.0$ & activator $136 \mathrm{kDa}$ subunit (RFC-36) & P40937 & HJU & $M(9)$ \\
\hline $70 / 5.8$ & $\begin{array}{l}\text { DNA-binding protein SATB1, C-terminal fragment } \\
\left({ }^{\star} \text { SATB1(C)) }\right.\end{array}$ & Q01826 & JU & W (ref. 22) \\
\hline $100 / 7.1-7.5$ & elongation factor 2 (EF-2) & P13639 & HJU & M (17) \\
\hline $97 / 4.6$ & endoplasmin & P14625 & HJU & $M(14), P$ \\
\hline $24 / 5.5$ & glutathione S-transferase P (GSTP) & P09211 & HJU & $M(23), P$ \\
\hline $60 / 5.2$ & $60 \mathrm{kDa}$ heat shock protein, mitochondrial (hsp 60) & P10809 & HJU & W \\
\hline $86 / 5.0$ & heat shock protein hsp $90-\alpha$ & P07900 & HJU & W \\
\hline $30 / 4.5-4.7$ & keratin, type I cytoskeletal 18 , fragment & P05783 & $\mathrm{HU}$ & $\mathrm{M}(16$, aa $236-364)$ \\
\hline $45 / 5.2$ & lamin $\mathrm{B} 1, \mathrm{C}$-terminal fragment $\left({ }^{*} \mathrm{Lb} 1(\mathrm{C})\right)$ & P20700 & HJU & $\mathrm{M}(24$, aa $235-577)$ \\
\hline $68 / 5.5$ & mitochondrial stress-70 protein (grp75) & P38646 & HJU & $M$ (ref. 7) \\
\hline $80 / 6.0$ & MUTS protein homolog 5 MutS- 5 & 043196 & JU & $\mathrm{M}(17)$ \\
\hline $95 / 5.3$ & myosin heavy chain, nonmuscle type $A$, fragment & P35579 & HJU & $\mathrm{M}(39$, aa $1220-1932)$ \\
\hline $57 / 6.0$ & probable protein disulfide isomerase ER-60 (ER-60 var) & P30101 & HJU & $M(11)$ \\
\hline $35 / 4.4$ & proliferating cell nuclear antigen PCNA & P12004 & HJU & W \\
\hline $39 / 4.6$ & $\begin{array}{l}\text { 40S ribosomal protein SA), C-terminal fragment } \\
\left({ }^{\star} \text { LBP-p40(C)) }\right.\end{array}$ & P08865 & HJU & $\mathrm{M}(8$, aa $18-212, \mathrm{~W})$ \\
\hline $130 / 5.0$ & $\begin{array}{l}\text { sarcoplasmic/endoplasmic reticulum calcium ATPase } \\
\text { isoform } 3 \text { (ER-ATPase) }\end{array}$ & Q93084 & HJU & M (13) \\
\hline $60 / 5.9$ & T-complex protein $1, \alpha$-subunit (TCP- $1 \alpha)$ & P17987 & HJU & $M(10)$ \\
\hline $57 / 6.7$ & T-complex protein 1 , delta-subunit $(\mathrm{TCP}-1 \delta)$ & P50991 & HJU & M (14) \\
\hline $59 / 5.5$ & T-complex protein 1 , epsilon-subunit) TCP-1 $\varepsilon$ ) & P48643 & HJU & $\mathrm{P}$ \\
\hline $58 / 5.6$ & T-complex protein 1 , theta-subunit) TCP-1 $\theta$ ) & P50990 & HJU & $\mathrm{P}$ \\
\hline $53 / 5.0$ & tubulin- $\alpha-4$ chain (tub- $\alpha$ ) & P05215 & HJU & W \\
\hline $51 / 5.3$ & $\begin{array}{l}\text { tubulin- } \alpha 4 \text { chain (modified isoform of fragment, } \\
{ }^{*} \text { tub- } \alpha\end{array}$ & P05215 & HJU & M (13) \\
\hline $50 / 4.8$ & tubulin $\beta-1$ chain (tub- $\beta$ ) & P07437 & HJU & $\mathrm{P}$ \\
\hline $30 / 5.0$ & vimentin C-terminal fragment & P08670 & HJU & $\mathrm{M}(9$, aa $188-449)$ \\
\hline $50 / 4.8$ & tubulin $\beta-1$ chain (tub- $\beta$ ) & P07437 & HJU & \\
\hline
\end{tabular}

Annotations as in Table 1. The range of the respective amino acid sequences covered by mass fingerprinting is indicated in case of protein fragments 

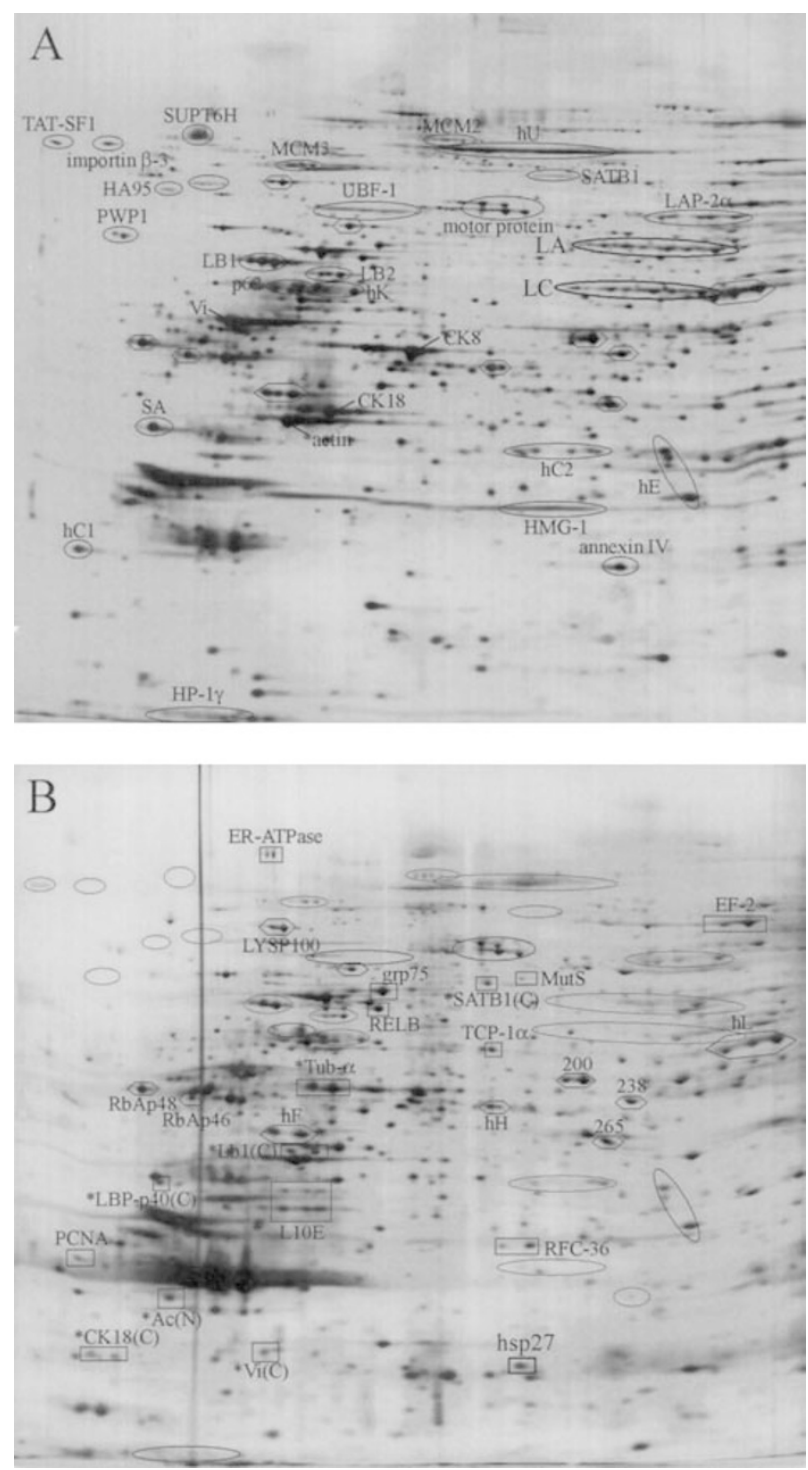

Figure 6 Nuclear matrix protein alterations are highly similar irrespective of the apoptosis induction mechanism and the cell type. $2 \mathrm{D}$ nuclear matrix protein pattern of control U937 cells (A) and U937 cells $6 \mathrm{~h}$ after UV lighttreatment (B), displaying approximately $50 \%$ chromatin condensation. Annotations: circles, proteins disappearing or decreased during apoptosis: hexagons, proteins maintained during apoptosis; rectangles, proteins accumulated during apoptosis. Note that essentially the same alterations were observed during Fas-induced apoptosis in Jurkat cells (Figures 3, 5) spots including hsp90 and an unknown protein p92/5.5-5.9 completely disappeared from the cytosol of apoptotic cells Figure 7), indicating regulated processes. Other new spots did not have counterparts in the control cytosol fraction (not shown) and might represent apoptosis-related protein isoforms, modified proteins or degradation products.

\section{Proteins maintained during ACC}

In total, 285 NMP spots present in controls were also detected in nuclear matrices isolated after completion of chromatin condensation at $8 \mathrm{~h}$ after induction of apoptosis. While many of these spots were of low intensity, a few imposed as relatively prominent and ubiquitously occurring. Amongst the latter we identified the chaperones grp78, hsc70 and ER-60; the hnRNPs F, H and L; further HP1 $\beta$, LYSP100, numatrin B23, RbAp46/48, and hNMP 184, hNMP 200, ${ }^{9}$ hNMP $238^{6}$ and hNMP265 ${ }^{8}$ (Table 3). Recently we described common reassembling NMPs, which have been characterized by their dialysis properties similar to those of intermediate proteins. ${ }^{7}$ These reassembling nuclear matrix proteins were considered to potentially represent structural nuclear proteins. Intriguingly, most of these proteins were recognized as being largely unaffected during ACC, suggesting their contribution to a residual core nuclear scaffold.

\section{Discussion}

In this study we demonstrated that one of the morphologic hallmarks of apoptosis, chromatin condensation, is accompanied by complex, but uniform, alterations of the nuclear matrix protein composition, largely irrespective of the cell type or apoptosis induction mechanism. Apoptosis-induced nuclear alterations such as caspase-mediated cleavage of e.g. nuclear lamins, ${ }^{15}$ MCM $3,{ }^{21}$ LAP2- $\alpha,{ }^{23}$ LSP-1, ${ }^{40}$ NuMA, ${ }^{41}$ SATB $1,{ }^{22}$ hnRNP-C ${ }^{18}$ and hnRNP- ${ }^{45}$ during apoptosis have been described and were observed as well by proteome analysis (Figures 3, 5 and Table 1). In addition to notifying protein cleavage processes, it was our intention to investigate the contribution of proteins to a potential nuclear scaffold and the implication of protein cleavage with apoptotic chromatin condensation (ACC).

Treatment of cells with the phosphatase inhibitor orthovanadate allowed to determine a point of no return towards chromatin condensation by $3 \mathrm{~h}$ after Fas-induction in Jurkat cells. This time point was used to determine

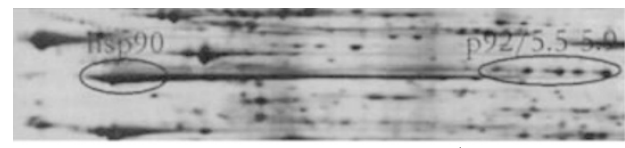

control Jurkat cytosol

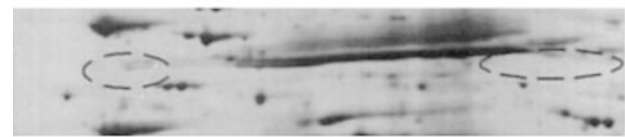

apoptotic Jurkat cytosol

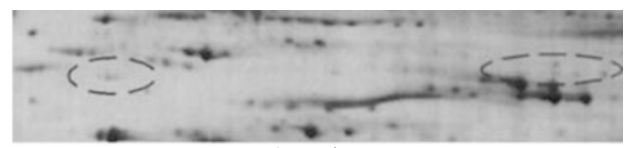

control Jurkat NM

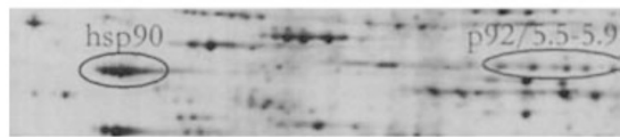

apoptotic Jurkat NM

Figure 7 Indications for nuclear translocation of hsp90 and p92/5.5-5.9 during apoptosis. Corresponding 2D gel sections of cytosolic proteins and NMPs of control Jurkat cells and apoptotic Jurkat cells $8 \mathrm{~h}$ after Fas-induction, respectively. During ACC the acidic isoforms of hsp90 and p92/5.5-5.9 disappeared from the cytosol and appeared in the nuclear matrix fraction 
Table 3 Nuclear matrix proteins apparently unaffected during ACC (indicated in Figure 5).

\begin{tabular}{|c|c|c|c|c|c|}
\hline \multirow[b]{2}{*}{ hNMP- No. } & \multirow[b]{2}{*}{ Mw/pl } & \multirow[b]{2}{*}{ protein name/spot designation } & \multicolumn{3}{|l|}{ Swiss-Prot } \\
\hline & & & GenBank Acc. No. & observed in & Identified by \\
\hline 176 & $51 / 4.5$ & $\begin{array}{l}\text { chromatin assembly factor } 1 \text { P48 subunit } \\
\text { (RBAP48) }\end{array}$ & Q09028 & HJU & A (ref. 7) \\
\hline 210 & $46 / 4.8$ & $\begin{array}{l}\text { histone acetyltransferase type B subunit } 2 \\
\text { (RBAP46) }\end{array}$ & Q16576 & HJU & $\mathrm{P}$ (ref. 7) \\
\hline 389 & $24 / 4.6$ & chromobox protein homolog 1 (HP1 $\beta)$ & P23197 & HJU & M (19) \\
\hline 80 & $78 / 4.9$ & $78 \mathrm{kDa}$ glucose regulated protein grp78 & P11021 & HJU & $\mathrm{P}$ (ref. 7) \\
\hline 238 & $54 / 6.5$ & hNMP 238 & AJ010058 & HJU & A (ref. 6) \\
\hline 200 & $56 / 6.4$ & hNMP 200 & AJ131186 & HJU & A (ref. 9) \\
\hline 265 & $47 / 6.4$ & hNMP 265 & D21853 & $\mathrm{HJU}$ & A (ref. 8) \\
\hline 248,254 & $46 / 5.2$ & hnRNP F (hF) & P52597 & HJU & W (ref. 3) \\
\hline 233 & $53 / 5.9$ & hnRNP H (hH) & P31943 & $\mathrm{HJU}$ & W, M (ref. 5) \\
\hline 234 & $53 / 5.9$ & hnRNP H $(\mathrm{hH})$ & P55795 & HJU & W, M (ref. 5) \\
\hline $266-269$ & $65 / 7.1-7.9$ & hnRNP L (hL) & P14866 & HJU & A, M, L (ref. 3) \\
\hline 85 & $71 / 5.3$ & $\begin{array}{l}\text { heat shock cognate } 71 \mathrm{kDa} \text { protein } \\
\text { (hsc70) }\end{array}$ & P11142 & HJU & A (ref. 7 ) \\
\hline 293 & $100 / 5.1$ & $\begin{array}{l}\text { lymphoid restricted homolog of SP100 } \\
\text { (LYSP100 protein) }\end{array}$ & Q13342 & HJU & M (14) \\
\hline 069 & $38 / 4.8$ & nucleophosmin (numatrin B23) & P06748 & HJU & A (ref. 3) \\
\hline
\end{tabular}

Annotations as in Table 1.

nuclear matrix proteome alterations preceding ACC in contrast to those becoming apparent after completion of ACC. Functional DISC assembly had clearly occurred resulting in the activation of caspase-8, while caspase-3 was found partially processed at that time (Figure 2). However, DNA fragmentation factor DFF-45, that mediates genomic DNA degradation during apoptosis, ${ }^{43}$ as well as poly (ADP-ribose) polymerase were hardly affected. Therefore, ACC was halted by orthovanadate treatment interfering with the progress of apoptosis downstream of DISC formation and presumably mitochondrial depolarization, but prior to cleavage of multiple nuclear proteins. Nonetheless, prolonged incubation showed that the cells were irreversibly committed to die, displaying a necrotic phenotype, suggesting that interfering with ACC does not necessarily elicit survival of cells (data not shown).

\section{Involvement of stress proteins during ACC}

Recently we described cytosolic heat shock proteins being affected during apoptosis. ${ }^{28}$ Some of these proteins are present as well in the nuclear matrix fraction. ${ }^{7}$ While ER-60, grp 78, hsp70, and PDI were found unaffected (Figure 5), the intensities of endoplasmin, mhsp 70 and TCP-1 $\delta$ were markedly increased in the nuclear matrix fraction and the TCP-1 isoforms $\alpha, \varepsilon$ and $\theta$, hsp27 and/or hsp90 appeared as a new upon chromatin condensation (Figures 4, 5, 6). A disruption of the nucleo-cytoplasmic barrier mediated by action of caspase- 9 has been described to occur during apoptosis, ${ }^{44}$ affecting the nuclear integrity and consequently the nuclear purification procedure. However, general contamination of nuclei by cytoplasmic constituents resulting in the apparently altered localization of these proteins can be ruled out in case of the early time-point, as only few proteins were found accumulated in a highly selective manner (Figure 4). In case of the later time-point such general contamination seems still unlikely, since none of many other abundant cytoplasmic proteins were found accumulated in the nuclear matrix fraction. However, copurification of insoluble protein aggregates such as cytoplasmic inclusions, which have been described to occur during apoptosis, ${ }^{45}$ with nuclear preparations cannot be ruled out.

This may apply to explain the increased amounts of tubulin $\alpha$ and $\beta$ and a tubulin $\alpha$-derived polypeptide found in nuclear fractions of apoptotic cells (Figure 4), as the tubulin network was described to collapse towards the nuclear surface. $^{46}$ TCP-1 isoforms are upregulated by unfolded proteins $^{47}$ and associate with tubulin, ${ }^{48}$ therefore they may have been copurified with collapsed tubulin.

On the other hand, accumulation of hsp27 and hsp90 in the nuclear matrix fraction appeared unrelated to the breakdown of the cytoskeleton. We observed that hsp27 accumulated in nuclei of various human tissue samples when kept on ice for more than 1 hour after surgery, while the cells displayed no signs of apoptosis (C Gerner, unpublished data). hsp90 translocation to the nucleus was also evident in serum-starved rat embryo cells rescued from apoptosis by addition of basic fibroblast growth factor (C Gerner, C Schamberger and C Cerni, unpublished data).

Compromising cytoplasmic hsp90 activity has been demonstrated to uncover cryptic genetic variations, leading to the expression of new traits in Drosophila. ${ }^{49}$ Our data may indicate that stress-induced hsp90 translocation to the nucleus may affect and partially reorganize chromatin.

\section{DNA replication and repair during apoptosis}

Proliferating cell nuclear antigen, replication factor RF-C36 and ribosomal protein $\mathrm{L} 10 \mathrm{E}$ have been implicated with replication and DNA repair. ${ }^{40,50}$ Interestingly, these proteins were found accumulated in the nuclear matrix fraction not only during apoptosis, but also in normal HeLa cells during G1/S transition (C Gerner and W Mikulits, unpublished data). This observation may suggest the induction of replicative foci and of DNA repair during apoptosis as described by others. ${ }^{51-54}$ This interpretation was corroborated by our finding that the 
${ }^{3} \mathrm{H}$-thymidine incorporation rate was increased by more than $30 \%$ within $4 \mathrm{~h}$ upon treatment of Jurkat cells with anti-Fas antibody (not shown).

\section{Disassembly of the transcription apparatus}

The nuclear matrix has been claimed to provide a spatial support for transcription and splicing activity. ${ }^{55,56}$ hnRNP proteins are abundant constituents of the nuclear matrix and are known to essentially contribute to transcription, splicing and mRNA transport. ${ }^{37}$ The observed depletion of the hnRNPs C1/ 2, E1/2, $\mathrm{K}$ and $\mathrm{U}$ in addition to the transcription factors TAT SF1 and UBF-1 may therefore be interpreted as indicative for a disassembly of the transcription and splicing apparatus during apoptosis upon loosing an ordered scaffolding.

\section{Evidence for a core nuclear skeleton}

At present the nature and function of many nuclear proteins have not yet been fully established, awaiting further investigation. ${ }^{57,58}$ It is still an open question whether the network of proteins observed by electron microscope imaging of the interphase nucleus ${ }^{59-61}$ is formed by own filamentous structural proteins, or by interacting proteins that are members of metabolically active complexes involved in nucleic acid metabolism, or by both types of components. ${ }^{62}$ Hitherto, only a few proteins, as nuclear lamins, nucleoplasmic myosin, actin and actin-binding proteins, the nuclear pore complex protein $\mathrm{p} 270 / \mathrm{Tpr}$ and the nuclear mitotic apparatus protein (NuMA) have been attributed a role as nuclear filamentous proteins. ${ }^{63-65}$

Consideration of the ACC phenomenology, as depicted in Figure 1, implies the existence of a residual nonchromatin core nuclear scaffold abandoned after chromatin has condensed. Fluorescence microscopy of a GFP-fusion construct of the abundant nuclear matrix protein hNMP 200 (Figure 1) suggests that proteins contribute to this scaffold. Several highly abundant nuclear matrix proteins, some of which may be implicated in functioning as structural supports of the nucleus, ${ }^{7}$ were found largely maintained during apoptosis (Figure 5). These nuclear matrix proteins might establish a protein network where chromatin and the transcriptional and splicing apparatus attach to on functional demand. These attachments might be relieved during ACC.

\section{Proteins mediating chromatin - nuclear matrix interactions}

Only subtle changes of the NMPs were observed when nuclei entered a committed state for ACC. Only 20 out of more than 300 spots were found substantially decreased, where as few proteolytic fragments generated by the action of caspases became detectable. Hence, most NM constituents appeared essentially unaffected. These data indicate that the apoptotic point of no return may be passed before most nuclear caspase targets are substantially degraded. It is remarkable that many nuclear matrix proteins considerably decreased at the committed state are chromatin-binding proteins such as SUPT6H, ${ }^{30} \mathrm{HA}^{3},^{31}$ nuclear lamins, ${ }^{32}$
LAP $2 \alpha^{23}$ and SATB $1,{ }^{22}$ proteins potentially linking chromatin to a nuclear scaffold. Decrease of proteins was accomplished by either cleavage, as of e.g. nuclear lamins ${ }^{15}$ and LAP $2 \alpha,{ }^{23}$ or release into the cytosol as evident in case of HA95, previously referred to as p94/4.7. ${ }^{28}$ Likewise decrease of transcription factors TAT-SF $1^{33}$ and UBF-1, ${ }^{34}$ of transport proteins such as importin- $\beta^{35}$ or of the nuclear motor protein, might loosen chromatin-nuclear matrixinteractions. In addition, we observed degradation of LBPp40 during apoptosis, which has not been described before. Downregulation of LBP - p40 utilizing an antisense strategy has been demonstrated to induce apoptosis in HeLa cells, ${ }^{66}$ suggesting a further pro-apoptotic effect by LBP-p40 cleavage.

The specific features of the neutrophil nuclear matrix protein composition provided another evidence for a causal relation of NMP alterations with ACC. These abundant white blood cells naturally display condensed chromatin and polymorph nuclei. In a previous study we have compared the NMPs of these cells with those of monocytes and lymphocytes isolated from peripheral blood and have described the lack of otherwise abundant and ubiquitously occurring NMPs in these cells. ${ }^{4}$ Intriguingly, most of these NMPs were identical with those found to decrease or disappear in other cells during ACC (not shown). On the other hand, all of the NMPs apparently maintained during ACC were found still detectable in neutrophils (not shown). These data corroborated the suggestion that many of the NMP alterations observed were intimately linked to the chromatin condensation process.

Recently it was suggested that DNA itself profoundly contributes to maintenance and organization of the nuclear structure. ${ }^{58}$ The present data suggest a critical contribution of mediator proteins linking chromatin to dynamic complexes finally forming a nuclear protein scaffold. Thus, chromatin condensation may result from depletion of such linker proteins releasing chromatin from a nuclear scaffold.

\section{Materials and Methods}

\section{Cell culture and induction of apoptosis}

Jurkat, U937, wild-type and hNMP 200-transfected HeLa cells were routinely cultivated in RPMI-1640, supplemented with $10 \%$ fetal calf serum (FCS) at $37^{\circ} \mathrm{C}$ in a humidified atmosphere containing $5 \% \mathrm{CO}_{2}$. For induction of apoptosis, Jurkat cells were washed in serum-free medium and re-seeded at a density of $10^{5}$ cells $/ \mathrm{ml}$ in medium containing 1\% FCS. Apoptosis was induced $15 \mathrm{~min}$ thereafter by adjusting to $50 \mathrm{ng} / \mathrm{ml}$ anti-Fas antibody (Clone $\mathrm{CH}-11$, Upstate Biotechnology, Lake Placid, NY, USA), $1.25 \mu \mathrm{M}$ Staurosporine (Calbiochem, La Jolla, CA, USA) or $5 \mu \mathrm{M}$ camptothecin (Sigma) in case of Jurkat and U937 cells, or $2.5 \mu \mathrm{M}$ Staurosporine in case of HeLa cells. Alternatively, cells were treated with $30 \mathrm{~J} / \mathrm{m}^{2} \mathrm{UV}$-light (254 nm) in HBSS at a density of $10^{6}$ cells $/ \mathrm{ml}$, cells were centrifuged and re-seeded in RPMI-1640. Scoring of apoptosis and viability was performed as described. ${ }^{22}$ Inhibition of chromatin condensation was accomplished by adjusting the medium to $300 \mu \mathrm{M}$ orthovanadate $2.5 \mathrm{~h}$ after anti-Fas treatment. After further $5.5 \mathrm{~h}$ cells were processed for immunoblot and microscopic analysis. 


\section{Microscopy}

HeLa cells expressing hNMP 200-GFP-chimeras were grown on coverslips, fixed in $2 \%$ formaldehyde/PBS at RT for $20 \mathrm{~min}$ and permeabilized in $0.5 \%$ Triton X-100/PBS for $5 \mathrm{~min}$. DNA was counterstained with $1 \mu \mathrm{g} / \mathrm{ml}$ Hoechst-33258 (Calbiochem) for 2 min. Fluorescence microscopy was performed on a Nikon Eclipse TE300 (equipped with TE-FM epi-fluorescence) inverted light microscope. For electron microscopy Jurkat cells were fixed in $2.5 \%(\mathrm{v} / \mathrm{v})$ glutaraldehyde in $0.1 \mathrm{M}$ sodium cacodylate buffer, $\mathrm{pH} 7.2$, for $60 \mathrm{~min}$ at $4^{\circ} \mathrm{C}$. $^{67}$ Following rinses in buffer, the cultures were post-fixed in $1 \%(\mathrm{w} / \mathrm{v})$ $\mathrm{OsO}_{4}$ in $0.1 \mathrm{M}$ acetate buffer, $\mathrm{pH} \mathrm{6.0,} \mathrm{dehydrated} \mathrm{in} \mathrm{a} \mathrm{graded} \mathrm{series} \mathrm{of}$ ethanol and embedded in Epon. Ultrathin sections were viewed both unstained and stained with uranyl and lead salts in a Philips EM 400 electron microscope.

\section{Isolation of the nuclear matrix}

The nuclear matrix preparation protocol was detailed previously. ${ }^{3}$ In brief, cells were lysed in $0.05 \%$ Nonidet P-40 in hypotonic buffer (10 mM HEPES/ $\mathrm{NaOH}, \mathrm{pH} 7.4,10 \mathrm{mM} \mathrm{NaCl}, 3 \mathrm{mM} \mathrm{MgCl}$ ). Nuclei were pelleted at $170 \mathrm{~g}$ for $10 \mathrm{~min}$ and the resulting supernatant centrifuged at $100000 \mathrm{~g}$ for $60 \mathrm{~min}$ to yield the cytosol. The nuclei were further purified by shearing, sucrose step centrifugation and detergent treatment and incubated in nuclease digestion buffer (10 mM Pipes, pH 6.8, $50 \mathrm{mM} \mathrm{NaCl}, 3 \mathrm{mM} \mathrm{MgCl} 2,0.25 \%$ Triton X$100,300 \mathrm{mM}$ sucrose) including $100 \mathrm{U} / \mathrm{ml}$ of DNAse I (Sigma) for $15 \mathrm{~min}$ at RT. After salt extraction the nuclear matrices were solubilized in sample buffer, consisting of $10 \mathrm{M}$ urea, $4 \% \mathrm{CHAPS}$, $0.5 \%$ SDS, $100 \mathrm{mM}$ DTT supplemented with $2 \%$ (v/v) ampholyte pH 7-9 (Merck). Largely intact nuclear matrix structures from Jurkat cells were obtained until up to eight hours after anti-Fas treatment.

\section{Two-dimensional electrophoresis and image analysis}

High resolution two-dimensional gel electrophoresis was carried out by modification of the method of Hochstrasser et al. ${ }^{68}$ using the Protean II xi electrophoresis system (Bio-Rad). As outlined previously, ${ }^{3} 70 \mu \mathrm{g}$ of NM protein samples were loaded on the first dimension tube gels. The second dimension was run on $10 \%$ polyacrylamide slab gels. Gels were silver stained by the method of Wray et al. ${ }^{69}$ Scanning of gels, comparative spot pattern analysis and determination of the integrated optical densities was accomplished with the Biolmage Investigator system (Biolmage, Ann Arbor, MI, USA), using the '2-D Analyzer ${ }^{\mathrm{TM}} \mathrm{V}$ 6.1 ' software package. The described protein spot alterations were reproduced at least three times.

\section{Immunoblot analysis}

For Western analysis, cell lysates were separated by $10 \%$ SDSPAGE, transferred to Hybond $P$ membranes (Amersham Pharmacia Biotech), blocked with $5 \%$ non-fat dried milk in TBST $(50 \mathrm{mM} \mathrm{Tris} / \mathrm{HCl}$ $\mathrm{pH} 7.5,150 \mathrm{mM} \mathrm{NaCl}, 0.1 \%$ Tween-20) for $1 \mathrm{~h}$ and incubated with antibodies recognizing caspase-8 (NeoMarkers, Fremont, CA, USA), caspase-3 (Santa Cruz Biotechnology, Santa Cruz, CA, USA), cleaved caspase-3 (Cell Signaling Technology, Beverly, MA, USA), PARP (R\&D Systems, Minneapolis, MN, USA), DFF-45 (StressGene, Victoria, Canada), $\beta$-Actin (Sigma) diluted in TBST containing $1 \%$ non-fat dried milk. The ECL Plus Western blotting detection system (Amersham Pharmacia Biotech) was used according to the instructions of the manufacturer.

\section{Identification of protein spots}

Identification of antigens in the 2D pattern by Western analysis was performed as described recently. ${ }^{70}$ For MS fingerprinting, Coomassie blue-stained proteins were directly cut out of preparative gels. Matrixassisted Laser desorption ionization-time-of-flight (MALDI-TOF) of tryptic protein hydrolysates was carried out essentially as described by Fountoulakis and Langen. ${ }^{71}$ Protein identification was accomplished by means of 'Peptldent' software ${ }^{72}$ made accessible by ExPASy (Expert Protein Analysis System). Proteins were considered as identified by means of MS-fingerprinting when data of at least 8 peptides representing more than $70 \%$ of the obtained peptide peaks unequivocally correlated with a published sequence. Furthermore, $\mathrm{Mw} / \mathrm{pl}$ values were compared with calculated data obtained with the 'Compute $\mathrm{pl} / \mathrm{Mw}^{\text {' software }}{ }^{73}$ made accessible by ExPASy and with data of $2 \mathrm{D}$ databases. ${ }^{74}$

\section{Acknowledgements}

The authors wish to thank Hynda K Kleinman (NIH, MD) for providing the anti-LBP-p40 antibody and Editha Bayer and Dieter Gelbmann for excellent technical assistance. This work was supported by a grant from the Institute of Cancer Research, Vienna, Austria.

\section{References}

1. Berezney R (1991) The nuclear matrix: A heuristic model for investigating genomic organization and function in the cell nucleus. J. Cell Biochem. 47: 109123

2. Berezney R and Jeon KW (1995) Structural and Functional Organization of the Nuclear Matrix. Int. Rev. Cytol. 162A-162B

3. Gerner C, Holzmann K, Grimm R and Sauermann G (1998) Similarity between nuclear matrix proteins of various cells revealed by an improved isolation method. J. Cell Biochem. 71: 363-374

4. Gerner $C$ and Sauermann $G$ (1999) Nuclear matrix proteins specific for subtypes of human hematopoietic cells. J. Cell Biochem. 72: 470-482

5. Holzmann K, Korosec T, Gerner C, Grimm R and Sauermann G (1997) Identification of human common nuclear-matrix proteins as heterogeneous nuclear ribonucleoproteins $\mathrm{H}$ and $\mathrm{H}^{\prime}$ by sequencing and mass spectrometry. Eur. J. Biochem. 244: 479-486

6. Holzmann K, Gerner C, Korosec T, Pöltl A, Grimm R and Sauermann G (1998) Identification and characterization of the ubiquitously occurring nuclear matrix protein NMP 238. Biochem. Biophys. Res. Com. 252: 39-45

7. Gerner C, Holzmann K, Meissner M, Gotzmann J, Grimm R and Sauermann G (1999) Reassembling proteins and chaperones in human nuclear matrix protein fractions. J. Cell Biochem. 74: 145-151

8. Holzmann K, Gerner C, Pöltl A, Schäfer R, Obrist P, Ensinger C, Grimm R and Sauermann $G$ (2000) A human common nuclear matrix protein homologous to eukaryotic translation initiation factor 4A. Biochem. Biophys. Res. Commun. 267: 339-344

9. Gotzmann J, Gerner C, Meissner M, Holzmann K, Grimm K, Mikulits W and Sauermann G (2000) hNMP 200: A novel human common nuclear matrix protein combining structural and regulatory functions. Exp. Cell Res. 261: 166-179

10. Steller H (1995) Mechanisms and genes of cellular suicide. Science 267: 14451449

11. Green DR (1998) Apoptotic pathways: the roads to ruin. Cell 94: 695-698

12. Cohen GM (1997) Caspases: the executioners of apoptosis. Biochem. J. 326: $1-16$

13. Thornberry NA and Lazebnik Y (1998) Caspases: enemies within. Science 281: $1312-1316$

14. Slee EA, Adrain C and Martin SJ (1999) Serial killers: ordering caspase activation events in apoptosis. Cell Death Differ. 11: 1067-1074 
15. Oberhammer FA, Hochegger K, Fröschl G, Tiefenbacher R and Pavelka M (1994) Chromatin condensation during apoptosis is accompanied by degradation of lamin $A+B$, without enhanced activation of cdc2 kinase. J. Cell. Biol. 126: 827-837

16. Tinnemans MM, Lenders MH, ten Velde GP, Ramaekers FC and Schutte B (1995) Alterations in cytoskeletal and nuclear matrix-associated proteins during apoptosis. Eur. J. Cell Biol. 68: 35-46

17. Weaver VM, Carson CE, WalkerPR, Chaly N, LachB, Raymond Y, Brown DL and Sikorska M (1996) Degradation of nuclear matrix and DNA cleavage in apoptotic thymocytes. J. Cell Sci. 109: 45-56

18. Waterhouse N, Kumar S, Song Q, Strike P, Sparrow L, Dreyfuss G, Alnemri ES, Litwack G, Lavin M and Watters D (1996) Heteronuclear ribonucleoproteins C1 and C2, components of the spliceosome, are specific targets of interleukin 1betaconverting enzyme-like proteases in apoptosis. J. Biol. Chem. 271: 2933529341

19. Martelli AM, Bareggi R, Bortul R, Grill V, Narducci P and Zweyer M (1997) The nuclear matrix and apoptosis. Histochem. Cell Biol. 108: 1-10

20. Gerner C, Seelos C and Sauermann G (1998) Alteration of nuclear matrix protein composition during apoptosis in rat embryo cells. Exp. Cell Res. 238: 472-480

21. Schwab BL, Leist M, Knippers R and Nicotera P (1998) Selective proteolysis of the nuclear replication factor MCM3 in apoptosis. Exp. Cell Res. 238: 415-421

22. Gotzmann J, Meissner M and Gerner C (2000) The fate of the nuclear matrixassociated-region-binding protein SATB1 during apoptosis. Cell Death Differ. 7 $425-438$

23. Gotzmann J, Vlcek S and Foisner R (2000) Caspase-mediated cleavage of the chromosome-binding domain of lamina-associated polypeptide 2. J. Cell Sci. 113: $3769-3780$

24. Wyllie AH (1980) Glucocorticoid-induced thymocyte apoptosis is associated with endogenous endonuclease activation. Nature 284: 555-556

25. Arends MJ, Morris RG and Wyllie AH (1990) Apoptosis. The role of the endonuclease. Am. J. Pathol. 136: 593-608

26. Allera C, Lazzarini G, Patrone E, Alberti I, Barboro P, Sanna P, Melchiori A Parodi S and Balbi C (1997) The condensation of chromatin in apoptotic thymocytes shows a specific structural change. J. Biol. Chem. 272: 1081710822

27. Sahara S, Aoto M, Eguchi Y, Imamoto N, Yoneda $Y$ and Tsujimoto $Y$ (1999) Acinus is a caspase-3-activated protein required for apoptotic chromatin condensation. Nature 401: 168-173

28. Gerner C, Fröhwein U, Gotzmann J, Bayer E, Gelbmann D, Bursch W and Schulte-Hermann R. (2000) The Fas-induced Apoptosis Analyzed by High Throughput Proteome Analysis. J. Biol. Chem. 275: 39018-39026

29. Ku NO, Liao J and Omary MB (1997) Apoptosis generates stable fragments of human type I keratins. J. Biol. Chem. 272: 33197-33203

30. Chiang PW, Wang S, Smithivas P, Song WJ, Ramamoorthy S, Hillman J, Puett S Van Keuren ML, Crombez E, Kumar A, Glover TW, Miller DE, Tsai CH, Blackburn CC, Chen XN, Sun Z, Cheng JF, Korenberg JR and Kurnit DM (1996) Isolation and characterization of the human and mouse homologues (SUPT4H and Supt4h) of the yeast SPT4 gene. Genomics 34: 328-333

31. Martins SB, Eide T, Steen RL, Jahnsen T, Skalhegg BS and Collas P (2000) HA95 is a protein of the chromatin and nuclear matrix regulating nuclear envelope dynamics. J. Cell. Sci. 113: 3703-3713

32. Glass JR and Gerace L (1990) Lamins $A$ and $C$ bind and assemble at the surface of mitotic chromosomes. J. Cell. Biol. 111: 1047-1057

33. Li XY and Green MR (1998) The HIV-1 Tat cellular coactivator Tat-SF1 is a general transcription elongation factor. Genes Dev. 12: 2992-2996

34. Kuhn A and Grummt I (1992) Dual role of the nucleolar transcription factor UBF trans-activator and antirepressor. Proc. Natl. Acad. Sci. USA 89: 7340-7344

35. Gorlich D and Kutay U (1999) Transport between the cell nucleus and the cytoplasm. Annu. Rev. Cell. Dev. Biol. 15: 607-660

36. Kinoshita K, Kaneda Y, Sato M, Saeki Y, Wataya-Kaneda M and Hoffmann A (1998) LBP-p40 binds DNA tightly through associations with histones H2A, H2B, and H4. Biochem. Biophys. Res. Commun. 253: 277-282

37. Krecic AM and Swanson MS (1999) hnRNP complexes: composition, structure, and function. Curr. Opin. Cell. Biol. 11(3): 363-371

38. Yan Y, Merchant AM and Tye BK (1993) Cell cycle-regulated nuclear localization of $\mathrm{MCM} 2$ and $\mathrm{MCM} 3$, which are required for the initiation of DNA synthesis at chromosomal replication origins in yeast. Genes Dev. 7: 2149-2160

39. Eissenberg JC and Elgin SC (2000) The HP1 protein family: getting a grip on chromatin. Curr. Opin. Genet. Dev. 10: 204-210
40. Brockstedt E, Rickers A, Kostka S, Laubersheimer A, Dorken B, WittmannLiebold B, Bommert K and Otto A (1998) Identification of apoptosis-associated proteins in a human Burkitt lymphoma cell line. Cleavage of heterogeneous nuclear ribonucleoprotein A1 by caspase 3. J. Biol. Chem. 273: 28057-28064

41. Gueth-Hallonet C, Weber Kand Osborn M (1997) Cleavage of the nuclear matrix protein NuMA during apoptosis. Exp. Cell. Res. 233: 21-24

42. Gohring F, Schwab BL, Nicotera P, Leist M and Fackelmayer FO (1997) The novel SAR-binding domain of scaffold attachment factor A (SAF-A) is a target in apoptotic nuclear breakdown. EMBO J. 16: 7361-7371

43. Tang D, Kidd VJ (1998) Cleavage of DFF-45/ICAD by multiple caspases is essential for its function during apoptosis. J. Biol. Chem. 273: 28549-28552

44. Faleiro $L$ and Lazebnik $Y$ (2000) Caspases disrupt the nuclear-cytoplasmic barrier. J. Cell Biol. 151: $951-960$

45. MacFarlane M, Merrison W, Dinsdale D and Cohen GM (2000) Active caspases and cleaved cytokeratins are sequestered into cytoplasmic inclusions in TRAILinduced apoptosis. J. Cell. Biol. 148: 1239-1254

46. Mills JC, Lee VM and Pittman RN (1998) Activation of a PP2A-like phosphatase and dephosphorylation of tau protein characterize onset of the execution phase of apoptosis. J. Cell. Sci. 111: 625-636

47. Yokota SI, Yanagi H, Yura T and Kubota H (2000) Upregulation of cytosolic chaperonin CCT subunits during recovery from chemical stress that causes accumulation of unfolded proteins. Eur. J. Biochem. 267: 1658-1664

48. Ritco-Vonsovici M and Willison KR (2000) Defining the eukaryotic cytosolic chaperonin-binding sites in human tubulins. J. Mol. Biol. 304: $81-98$

49. Rutherford SL and Lindquist S (1998) Hsp90 as a capacitor for morphological evolution. Nature 396: $336-342$

50. Mossi R and Hubscher U (1998) Clamping down on clamps and clamp loaders the eukaryotic replication factor C. Eur. J. Biochem. 254: 209-216

51. Khodarev NN, Sokolova IA and Vaughan AT (1998) Association between DNA cleavage during apoptosis and regions of chromatin replication. J. Cell. Biochem. 70: $604-615$

52. Gagandeep S, Novikoff PM, Ott Mand Gupta S (1999) Paclitaxel shows cytotoxic activity in human hepatocellular carcinoma cell lines. Cancer Lett. 136: 109-118

53. Li X, Traganos F and Darzynkiewicz Z (1994) Simultaneous analysis of DNA replication and apoptosis during treatment of $\mathrm{HL}-60$ cells with camptothecin and hyperthermia and mitogen stimulation of human lymphocytes. Cancer Res. 54: $4289-4293$

54. LaCount DJ and Friesen PD (1997) Role of early and late replication events in induction of apoptosis by baculoviruses. J. Virol. 71: 1530-1537

55. Jackson DA and Cook PR (1985) Transcription occurs at a nucleoskeleton. EMBO J. 4: $919-925$

56. Stein GS, van Wijnen AJ, Stein JL and Lian JB (1999) Interrelationships of transcriptional machinery with nuclear architecture. Crit. Rev. Eukaryot. Gene. Expr. 9: 183-190

57. Pederson T (1998) Thinking about a Nuclear Matrix. J. Mol. Biol. 277: 147-159

58. Pederson T (2000) Half a century of 'the nuclear matrix'. Mol. Biol. Cell 11: $799-$ 805

59. Capco DG, Krochmalnic G and Penman S (1984) A new method of preparing embedment-free sections for transmission electron microscopy: applications to the cytoskeletal framework and other three-dimensional networks. J. Cell. Biol. 98: $1878-1885$

60. Fey EG, Krochmalnic G and Penman S (1986) The nonchromatin substructures of the nucleus: the ribonucleoprotein (RNP)-containing and RNP-depleted matrices analyzed by sequential fractionation and resinless section electron microscopy. J. Cell. Biol. 102: 1654-1665

61. Jackson DA and Cook PR (1985) Transcription occurs at a nucleoskeleton. EMBO J. 4: 919-925

62. Tan JH, Wooley JC and LeStourgeon WM (2000) Nuclear matrix-like filaments and fibrogranular complexes form through the rearrangement of specific nuclear ribonucleoproteins. Mol. Biol. Cell. 11: 1547-1554

63. Marshall WF, Fung JC and Sedat JW (1997) Deconstructing the nucleus: global architecture from local interactions. Curr. Opin. Gen. Dev. 7: 259-263

64. Gueth-Hallonet C, Wang J, Harborth J, Weber K and Osborn M (1998) Induction of a Regular Nuclear Lattice by Overexpression of NuMA. Exp. Cell. Res. 243: $434-452$

65. Cordes VC, Reidenbach S, Rackwitz HR and Franke WW (1997) Identification of protein $\mathrm{p} 270 / \mathrm{Tpr}$ as a constitutive component of the nuclear pore complexattached intranuclear filaments. J. Cell. Biol. 136: 515-529 
66. Kaneda Y, Kinoshita K, Sato M, Saeki Y, Yamada R, Wataya-Kaneda M and Tanaka K (1998) The induction of apoptosis in HeLa cells by the loss of LBP-p40. Cell Death Differ. 5: 20-28

67. Kerr JFR, Gobe GC, Winterford CM and Harmon BV (1995) Anatomical methods in cell death. In: Methods in Cell Biology, Vol. 46, Schwartz LM, Osborne BA eds. (London: Academic Press Inc.) pp. 1-27.

68. Hochstrasser DF, Harrington MG, Hochstrasser AC, Miller MJ and Merill CR (1988) Methods for increasing the resolution of two-dimensional protein electrophoresis. Anal. Biochem. 173: 424-435

69. Wray W, Boulikas T, Wray V and Hancock R (1981) Silver staining of proteins in polyacrylamide gels. Anal. Biochem. 118: 197-203

70. Gotzmann J and Gerner C (2000) A method to produce Ponceau-replicas from blots: Applications for Western analysis. Electrophoresis 21: 523-525

71. Fountoulakis Mand Langen $\mathrm{H}$ (1997) Identification of proteins by matrix-assisted laser desorption ionization-mass spectrometry following in-gel digestion in lowsalt, nonvolatile buffer and simplified peptide recovery. Anal. Biochem. 250: $153-156$
72. Wilkins MR and Williams KL (1997) Cross-species protein identification using amino acid composition, peptide mass fingerprinting, isoelectric point and molecular mass: a theoretical evaluation. J. Theor. Biol. 186: 7-15

73. BjellqvistB, Hughes GJ, Pasquali Ch, Paquet N, Ravier F, SanchezJCh, Frutiger $S$ and Hochstrasser DF (1993) The focusing positions of polypeptides in immobilized $\mathrm{pH}$ gradients can be predicted from their amino acid sequences. Electrophoresis 14: 1023-1031

74. Celis JE, Rasmussen HH, Gromov P, Olsen E, Madsen P, Leffers H, Honore B, Dejgaard K, Vorum H, Kristensen DB, Østergaard M, Hauns A, Aagaard Jensen N, Celis A, Basse B, Lauridsen JB, Ratz GP, Andersen AH, Walbum E, Kjaergaard I, Andersen I, Puype M, Van Damme J and Vandekerckhove J (1995) The human keratinocyte two-dimensional protein database (update 1995): Mapping components of signal transduction pathways. Electrophoresis 16: $2177-2240$ 